\title{
THE DIAGNOSTIC IMPORTANCE OF GLYCOSURIA IN LEAD POISONING IN CHILDHOOD
}

\author{
BY \\ RONALD C. ROXBURGH and LEONARD HAAS \\ From the Queen Elizabeth Hospital for Children and The London Hospital
}

(RECEIVED FOR PUBLICATION JULy 24, 1958)

In 1926, McKhann described three cases of lead poisoning in small children; he noticed, among other symptoms and signs, that marked but transient glycosuria was present in two of the three cases. Seven years later McKhann and Vogt (1933) reviewed all the case notes of children with lead poisoning admitted to the Boston Infants and Children's Hospitals between the years 1924 and 1933. These amounted to 89 cases, and the presence of glycosuria had been noted 'frequently' especially in the presence of encephalopathy. In a similar review from New York Goettsch and Mason (1940) collected records of 39 cases of lead poisoning between 1923 and 1938; in this series the incidence of glycosuria was $20 \%$. In one of the cases glycosuria persisted for five weeks. More recently Ennis and Harrison (1950) found glycosuria in four out of 10 cases of lead poisoning. Burrows, RendleShort and Hanna (1951) reported that glycosuria was commonly found in such cases. Six years ago, one of us (R.C.R.) in conjunction with Millichap and Llewellin (1952) reported five cases of lead poisoning in young children due to ingestion of paint. It was noticed at that time that two of the cases had had glycosuria for a short period at the onset, but the diagnosis in those cases had been established on other evidence.

Further reports of childhood lead poisoning have come from Zak and Finkelstein (1952), Gianattasio, Bedo and Pirozzi (1952), Wilson, Thomson and Dent (1953), Byers, Maloof and Cushman (1954), Marsden and Wilson (1955), Tanis (1955), and O'Donohoe (1956). In many of these cases it had been noticed that glycosuria was present.

However, it had apparently been an incidental finding and the purpose of this paper is to show the diagnostic value of glycosuria, especially in the cases of lead poisoning without encephalopathy. In the following three cases, seen consecutively, it was the presence of marked glycosuria in the absence of a raised blood sugar level that led to a search for other evidence of lead poisoning.

\section{Case Reports}

Case 1. J.A. was a boy, aged $1 \frac{1}{2}$ years. He had been unwell for about two weeks with malaise and vomiting. Anorexia had been marked, there had been obvious weight loss and he was very constipated. It had been noticed that he had become very pale.

He was admitted to the Queen Elizabeth Hospital on August 13, 1957, for investigation. On examination, he was a pale listless child weighing $21 \mathrm{lb} .5 \mathrm{oz} .(9 \cdot 5 \mathrm{~kg}$.). He was fully conscious. There were no abnormal physical signs in the cardiovascular, respiratory or central nervous systems. The spleen tip was palpable. The urine showed a moderate amount of sugar, giving a yellow reduction of Benedict's reagent. Rothera's test was also positive and a trace of protein was found.

Laboratory investigations gave the following results: Blood haemoglobin, $50 \%$ (7.4 g.); R.B.C., 4.98 million per c.mm.; W.B.C., 8,200 per c.mm.; blood sugar, $92 \mathrm{mg} . \%$. Microscopic examination of the urine showed the presence of 20 red and 20 white blood cells per high power field. On August 20, while the blood sugar level was $88 \mathrm{mg}$. $\%$, the urine contained $470 \mathrm{mg}$. $\%$ of glucose.

In view of the persistence of glycosuria in an ill, listless and anaemic child, it was considered that the underlying cause might be lead poisoning. Further investigations showed that marked punctate basophilia of the red blood cells was present, radiographs of the radius and ulna showed a dense heavy metal band at the distal metaphysis, urinary coproporphyrins were greatly increased, and the urinary lead concentration was $0.56 \mathrm{mg}$. $/ \mathrm{l}$.

In view of these findings, the parents were further questioned about possible exposure to lead. They at once confirmed that the child had for the past three months been in the habit of chewing the paint off the edges of the window-sills and doors. Analysis of some of the paint scrapings showed a high lead content.

Progress and Treatment. In view of the relatively mild course of the illness, it was at first decided to withhold specific E.D.T.A. therapy and the acute symptoms subsided gradually, though the anaemia persisted. Glycosuria persisted for three weeks from the time of admission. Paper chromatography of the urine three months later showed a normal amino-acid excretion pattern and no evidence of glycosuria. Treatment with calcium di-sodium versenate was commenced orally on 
November 22 in a dosage of $1.75 \mathrm{~g}$. daily and following this the urine lead concentration rose from 0.03 to $6.0 \mathrm{mg} . / \mathrm{l}$. No side effects were noticed nor was there any recurrence of evidence of tubular damage. Now, nine months after the onset, there is no sign of mental deterioration. Treatment with versenate has been continued orally for five months and the urine lead concentration is still raised $(1.28 \mathrm{mg}$./1.).

Case 2. L.L., a girl, aged $6 \frac{1}{4}$ years, whose father is a house painter, was admitted to the Queen Elizabeth Hospital on August 30, 1957, on account of vomiting and malaise for two weeks, and abdominal colic for three days. It was later discovered that she had had pica at the age of 2 years. She was an ill afebrile child weighing $37 \mathrm{lb}$. $(16 \cdot 65 \mathrm{~kg}$.). She was fully conscious, but was very irritable and was slightly dehydrated. There were no abnormal physical signs in the cardiovascular, respiratory or alimentary systems. Neck stiffness and papilloedema were absent, but there was marked muscular hypotonia despite normal tendon reflexes. The urine was found to contain a trace of protein, gave a yellow reduction of Benedict's solution and a strongly positive Rothera's test. Laboratory investigation confirmed that the sugar was glucose. On microscopy there were eight W.B.C.s and moderate numbers of granular casts per one-sixth field.

Because of these findings, further investigations for lead poisoning were undertaken. In the blood, the haemoglobin was $55 \%(8 \cdot 14 \mathrm{~g}$.) and punctate basophilia was present. Radiographs of the radius and ulna showed the presence of a dense heavy metal line at the distal metaphysis and this sign was also present at the costochondral junctions as seen on the routine chest film. The urinary coproporphyrin output was greatly increased, as was the amino-acid output on paper chromatography. The urine lead concentration in a 24-hour specimen was $0.4 \mathrm{mg}$./l. The blood sugar level, in the presence of glycosuria, was $82 \mathrm{mg}$. \%. The blood urea was $52 \mathrm{mg}$. \%. Cerebrospinal fluid was not examined. The glucose tolerance curve was normal. In view of these conclusive findings, the parents were further questioned on the possible sources of lead at home, but apart from her father being a house painter, it was not possible to discover how lead had been ingested.

Progress and Treatment. The child rapidly lost her acute symptoms following rehydration and at first no treatment with versenate was given. Moderate glycosuria persisted for the first three weeks in hospital. Specific therapy with oral calcium di-sodium versenate was started on October 14, 1957, six weeks after admission. Dosage was $1 \cdot 2 \mathrm{~g}$. daily at first, later increased to $6 \cdot 0 \mathrm{~g}$. daily. The urine lead concentration rose from 0.6 to a maximum level of $3.5 \mathrm{mg}$./l. There were no ill-effects from this treatment but slight diarrhoea occurred when $6.0 \mathrm{~g}$. daily was being given, so this was reduced to $3.0 \mathrm{~g}$. daily, which was well tolerated. The child's general condition and mental state improved considerably after a week of treatment with versenate, suggesting that de-leading was of benefit to her metabolic processes.
By the end of four months on this treatment she had gained $14 \mathrm{lb} .(6 \cdot 3 \mathrm{~kg}$.) in weight and the haemoglobin had risen to $90 \%(13 \mathrm{~g}$.).

Case 3. Philip E., aged 4 years 8 months, was admitted in deep coma to the London Hospital on September 20, 1957.

He had been lethargic, moody, disinterested and lacking in appetite for some weeks. On the previous day he had complained of abdominal pain and had vomited. On the afternoon of admission he collapsed whilst playing in the street. He was admitted to another hospital, where he was found to be extremely drowsy and confused; his pupils were dilated and barely reacted to light; there was a flaccid left-sided hemiparesis. During the course of a few hours he sank into deep coma, and was transferred to the London Hospital for a neurosurgical opinion.

On admission the pupils were fixed, dilated and did not react to light. All limbs were flaccid and the deep tendon reflexes were absent. Both plantar responses were extensor. Firm supra-orbital pressure produced only faint response. The optic fundi appeared normal. The weight was $30 \mathrm{lb}$. (13.5 kg.).

He was considered to have rising intracranial pressure and, under local anaesthesia, burr holes were made. The ventricles could not be located. The cortex looked congested and plum-coloured; it was normal on biopsy.

Post-operatively, he had several epileptiform convulsions. He was given rectal hypertonic saline with a view to reducing intracranial pressure. On the morning after admission his condition had improved. He was conscious, though still confused and irrational, and was moving all his limbs. The tendon reflexes, all present, were brisker on the right and there was definite weakness of that side. The right plantar response was extensor, the left flexor. At this stage the urine was found to contain a considerable amount of sugar, being orange to Benedict's test. The blood sugar level was $85 \mathrm{mg}$. per $100 \mathrm{ml}$. The blood picture was as follows: haemoglobin, $49 \%$ (7.3 g./100 ml.); W.B.C. 13,300, polymorphs $50 \%$, lymphocytes $44 \%$, monocytes $5 \%$, metamyelocytes $1 \%$. There was moderate anisocytosis and poikilocytosis of unequally staining red cells. Platelets were plentiful.

Twenty-four hours later he appeared to have fully recovered. He was well orientated, alert and intelligent. There were no abnormal neurological signs. An air encephalogram was carried out. The ventricles on this occasion were located with ease, and were found to show a normal radiological pattern.

Thereafter, his clinical condition remained good. However, heavy glycosuria continued for three weeks. A normal sugar tolerance curve showed that this was due to a lowering of the renal threshold. This fact, considered together with the hitherto unexplained encephalopathy and the hypochromic anaemia, appeared to us highly suggestive of lead poisoning. The following investigations were therefore carried out: radiographs of the long bones showed increased density along the lines of the metaphyses; staining of a blood film with methylene blue showed many stippled cells; further 
examination of the urine revealed an excess of coproporphyrins; its total lead content was $0.65 \mathrm{mg}$. $/ 1$.

Oral calcium di-sodium versenate was commenced on October 15, 1957, in a dosage of $1 \mathrm{~g}$. daily, increased gradually until $3 \mathrm{~g}$. daily were given. The urinary output of lead excreted rose to figures between 0.6 and $1.6 \mathrm{mg} . / 1$. In addition three doses of $1 \mathrm{~g}$. of intravenous versenate were administered at weekly intervals. These caused the amount of lead in the urine to rise to $8.4,8$ and $3.67 \mathrm{mg} . / 1$. respectively. No side effects were noted and there was no evidence of further renal damage at any time. Glycosuria and excess coproporphyrinuria disappeared three and eight weeks after admission respectively. He was discharged after 12 weeks in hospital weighing $38 \mathrm{lb}$. (17 kg.) and out-patient treatment with oral versenate was continued. He was re-admitted on three occasions in January, April and July, 1958, for short periods of observation, and each time was given a further intravenous infusion of versenate. These led to lead excretions of $2 \cdot 5,1 \cdot 8$, and $1.5 \mathrm{mg} . / 1$. At present he is well and free from symptoms. The dense line on the radiograph has receded proximally from the metaphysis by several $\mathrm{mm}$; the blood picture is normal with a haemoglobin of $90 \%$ (13 g.) and there is no evidence of basophil stippling. Treatment was discontinued on July 10. However, lead excretion in the urine is still raised and fluctuates between 0.2 and $0.52 \mathrm{mg}$. $/ 1$.

\section{Sources of Lead}

The commonest cause of lead poisoning in small children is the ingestion of paint flakes containing lead (Chisolm and Harrison, 1956), and this proved to be the source in Case 1 of the present series. This child was in the habit of nibbling paint off the window sills and doors. In Case 2 of the series, the source of lead could not be determined. The father was a house painter but any connexion between this and the child's illness was denied. In Case 3 of the series a somewhat unusual source was incriminated. He always chewed objects within his grasp but never cot-sides or windowsills. His favourite occupation was drawing with coloured crayons. It was pointed out to us that the colours ranging from pale yellow to orange were made with lead chromate (Bonnell, 1957). Samples of the patient's crayons were therefore analysed in the Department for Research in Industrial Medicine at the London Hospital. This confirmed that the 'leads' of the yellow and the orange pencils have a lead content of $5 \%$. Furthermore the paints used to colour the outside of the crayons were also found to contain $5 \%$ of lead. This potential source of lead poisoning does not seem to have been reported in this country hitherto. As coloured pencils are present in every home it seems important to draw attention to their potential danger.

\section{Discussion}

It has been shown in these three cases of lead poisoning that glycosuria was occurring in the presence of a normal blood sugar level. There was also evidence of renal damage in Cases 1 and 2. All these abnormalities were transient; the glycosuria persisted for approximately three weeks in each case from the time of admission. In two of the cases the acute symptoms subsided after admission to hospital without the supervention of encephalopathy; it is possible that this type of case may be occurring in children without being diagnosed. It is significant that it was not only the severe case that was associated with glycosuria.

It is known from animal experiments that lead poisoning damages the renal tubule (Blackman, 1936). Marsden and Wilson (1955) found microscopic evidence of damage to the proximal convoluted tubule in two children who died of lead poisoning; both cases had exhibited glysosuria and amino-aciduria in life. The histological changes were those of intranuclear inclusions, giant nuclei, and fatty vacuolation of the cytoplasm.

According to Anderson (1954) the glycosuria that may accompany lead poisoning in childhood is apparently of renal origin since the blood sugar level is unaffected; it probably results from tubular damage. It must be concluded that the effect of the lead is to interfere with the intracellular enzyme systems which normally facilitate the re-absorption of glucose and amino-acids from the proximal tubules. It appears that this is a special feature of lead poisoning in childhood, since the occurrence of glycosuria is not a recognized pathological finding in adults with chronic lead poisoning.

However, glycosuria and amino-aciduria have been described in other metallic poisonings, e.g. mercury, in uranium toxicity in animals (Voegtlin and Hodge, 1949) in Wilson's hepato-lenticular degeneration, and in ferrous sulphate poisoning (Brown and Gray, 1955). A case of special interest was described by Chisolm, Harrison, Eberlein and Harrison (1955) in which, following lead poisoning in a child, transient glycosuria, amino-aciduria, hypophosphataemia and rickets occurred; this syndrome closely simulated the findings in the de Toni-Fanconi syndrome.

\section{Conclusions}

It is probable that glycosuria is present to some degree in most cases of childhood lead poisoning and this fact should be more widely appreciated. In any case of persistent renal glycosuria occurring in a 
child who is otherwise unwell, the diagnosis of lead poisoning must always be considered.

The experience gained during the treatment of the cases with oral calcium di-sodium versenate leads us to suggest that prolonged courses are without danger to the patient and, in addition, continue to enhance the renal excretion of lead in increased amounts. That the excretion of lead should be as complete as possible is shown by Henderson (1954) from Queensland, Australia, who gives evidence of the danger of chronic renal disease occurring in young adults who had been afflicted with lead poisoning in childhood. So far, no such series of cases has been reported in this country.

\section{Summary}

Three further cases of lead poisoning in children are described. The diagnosis of the condition was reached at an early stage after admission to hospital because of the discovery of glycosuria, which led to further tests for lead poisoning. The glycosuria persisted for three weeks. There was no evidence of residual renal damage at the end of six months. All three cases were treated with prolonged courses of oral calcium di-sodium versenate resulting in prolonged excretion of lead in the urine.

Evidence is put forward to suggest that coloured crayons of the yellow and orange ranges may be a danger to children on account of their content of lead chromate.

We are grateful to Dr. Helen Mackay, to Dr. C. T. Potter, and to Dr. Richard Dobbs for permission to publish these cases which were under their care: to Dr. J. A. Bonnell for much assistance, advice and many urine-lead estimations carried out in the Department for Industria! Medical Research at the London Hospital; to Dr. B. Levin for numerous laboratory investigations at the Queen Elizabeth Hospital.

REFERENCES

Anderson, J. A. (1954). In Textbook of Pediatrics, 6th ed. Ed. W. E. Nelson, p. 630. Philadelphia.

Best, C H. and Taylor, N. B. (1955). The Physiological Basis of Medical Practice, 6th ed. London.

Blackman, S. S. Jr. (1936). Bull. Johns Hopk. Hosp., 58, 384.

Bonnell, J. A. L. (1957). Personal communication.

Brown, R. J K. and Gray, J. D. (1955). Canad. med. Ass. J., 73, 192.

Burrows. N. F. E., Rendle-Short, J. and Hanna, D. (195i). Brit. med.J., 1, 329.

Byers, R. K., Maloof, C. A. and Cushman, M (1954) A.M.A. Amer. J. Dis. Child, 87, 548.

Chisolm, J. J. and Harrison, H. E. (1956). Pediatrics, 18, 943.

Chisolm, Harrison, C., Eberlein, W. R and Harrison, H. E. (1955). A.M.A. Amer. J. Dis. Child., 89, 159.

Ennis, J. M. and Harrison, H. E. (1950). Pediatrics, 5, 853.

Gianattasio, R. C., Bedo, A. V. and Pirozzi, M. J. (1952). A.M.A. Amer. J. Dis. Child., 84, 316

Goettsch, E. and Mason, H. H. (1940). Amer. J. Dis. Child., 59, 119.

Henderson, D. A. (1954). Aust. Ann. Med , 3, 219.

Marsden, H. B. and Wilson, V. K. (1955). 'Brit. med. J., 1, 324.

McKhann, C. F. (1926). Amer. J. Dis. Child., 32, 386.

- and Vogt, E. C. (1933). J. Amer. med Ass., 101, 1131.

Millichap, J. G., Llewellin, K. R. and Roxburgh, R. C. (1952), Lancet, 2,360.

O'Donohoe, N. V. (1956). Arch. Dis. Childh., 31, 321.

Tanis, A. L. (1955). A.M.A. Amer. J. Dis. Child., 89, 325.

Voegtlin, C. and Hodge. H. C. (1949). Pharmacology and Toxicology of Uranium Compounds. McGraw-Hill, New York.

Wilson, V. K., Thomson, M. L. and Dent C. E. (1953). Lancet, 2, 66

Zak, F. G. and Finkelstein, W. E. (1952). J. Mt Sinai Hosp., 19, 352 . 